\title{
Medical cover at Scottish football matches: have the recommendations of the Gibson Report been met?
}

\author{
Gary W Kerr, Stewart C Wilkie, Crawford A McGuffie
}

\begin{abstract}
Objectives-To determine if doctors providing medical care at Scottish football stadiums meet the standards recommended by the Gibson Report.

Methods-A postal questionnaire and telephone follow up of doctors involved with the 40 Scottish League teams.

Results-47\% of the doctors had not attended any relevant resuscitation courses and $72 \%$ had no training in major incident management.

Conclusions-The recommendations of the Gibson Report with regard to medical cover at football stadiums have not been fully implemented in Scotland.

(Br F Sports Med 1999;33:274-275)

Keywords: crowd disasters; Gibson Report; incident management; football

All crowd events have the potential to generate a major incident resulting in multiple casualties and fatalities. ${ }^{1}$ The most regular major crowd events in this country are football matches. Through the years there have been a number of crowd related catastrophes which are listed in table 1. We carried out a survey of the doctors attending football matches in Scotland in an attempt to establish the current level of training in aspects of emergency care and major incident management that would be essential if such a disaster were to occur today. Our aim was to ascertain if the standards recommended by the Gibson Report, ${ }^{2}$ which was published following the Hillsborough disaster, had been met.
\end{abstract}

\section{Methods}

A postal questionnaire was sent out via the clubs to the doctors officially involved with the 40 teams currently playing in the Scottish Football League. This was followed two months later by a telephone survey of non-responders. Figure 1 shows the questionnaire used.

\section{Results}

Responses were obtained from the doctors of 36 , clubs with four clubs stating that they did not

Table 1 Football stadium disasters

\begin{tabular}{lcc}
\hline Stadium & Year & Fatalities $(n)$ \\
\hline Ibrox & 1902 & 26 \\
Bolton Wanderers & 1946 & 33 \\
Ibrox & 1971 & 66 \\
Bradford & 1985 & 40 \\
Birmingham City & 1985 & 1 \\
Hysell & 1985 & 41 \\
Hillsborough & 1989 & 95 \\
\hline
\end{tabular}

\begin{tabular}{|l|l|}
\hline Club & \\
\hline Dr. & \\
\hline Contact number & \\
\hline $\begin{array}{l}\text { Have you attended any } \\
\text { of the following courses? }\end{array}$ & \\
\hline Advanced Life Support & Yes/No \\
\hline $\begin{array}{l}\text { Advanced Trauma Life } \\
\text { Support }\end{array}$ & Yes/No \\
\hline $\begin{array}{l}\text { Paediatric Advanced } \\
\text { Life Support }\end{array}$ & Yes/No \\
\hline $\begin{array}{l}\text { Major Incident Medical } \\
\text { Management \& Support }\end{array}$ & Yes/No \\
\hline \begin{tabular}{l} 
BASICS \\
\hline $\begin{array}{l}\text { Any other courses } \\
\text { eg Dip IMC (please specify) }\end{array}$
\end{tabular} & Yes/No \\
\hline $\begin{array}{l}\text { Is there a separate crowd } \\
\text { Dr. at the club? }\end{array}$ & Yes/No \\
\hline $\begin{array}{l}\text { Do you have a major } \\
\text { incident plan for the } \\
\text { stadium? }\end{array}$ & Yes/No \\
\hline $\begin{array}{l}\text { Is there a pre-match liaison } \\
\text { meeting with other } \\
\text { emergency personnel? }\end{array}$ & Yes/No \\
\hline $\begin{array}{l}\text { Would you find a training } \\
\text { course useful? }\end{array}$ & Yes/No \\
\hline
\end{tabular}

Figure 1 Postal questionnaire sent to doctors involved with 40 Scottish League football clubs to ascertain standards of medical care.

currently have a club doctor. Of these 36,14 $(39 \%)$ had attended one or more of the resuscitation based courses asked about, namely Advanced Life Support (ALS), Advanced Trauma Life Support (ATLS), Paediatric Advanced Life Support (PALS), and British Association for Immediate Care (BASICS). Of the $22(61 \%)$ doctors who had not attended any of the courses listed, five reported attendance at a variety of other courses intended to improve resuscitation skills. Therefore 17 (47\%) doctors had not attended any relevant resuscitation courses.

Twenty six $(72 \%)$ had no training in major incident management from either a Major Incident Medical Management and Support 
(MIMMS) course or BASICS course. Twenty $(56 \%)$ doctors were aware of the major incident plan for their stadium and 19 (53\%) held a regular liaison meeting with the other emergency services in the stadium.

Fifteen of the clubs had a separate crowd doctor but only 10 of the 14 clubs with average league match attendances for the 1997-1998 season of more than 3000 had a separate crowd doctor.

Twenty nine $(81 \%)$ of the doctors contacted felt that a course covering basic resuscitation skills and major incident management would be beneficial.

\section{Discussion}

As in previous football crowd disasters, an isolated incident such as the collapse of a crowd barrier or a wall can have devastating consequences. Crowd dynamics can change unpredictably and the flow of people within a confined area can rapidly lead to disaster if the pattern of movement cannot be accommodated. ${ }^{3}$ As the tenth anniversary of the Hillsborough disaster approaches, it may be that the medical cover at football grounds in Scotland would be insufficient to deal with such an eventuality.

As a consequence of the Hillsborough disaster, which resulted in 95 deaths, the Gibson Report was published in 1990. Its aim was to ensure that, in the event of another crowd disaster within a football stadium, the doctors present would have appropriate training to deal with the initial management. It went on to make recommendations about the provision of medical care at football matches, and other sports have also taken note of these. ${ }^{4}$

The report stated that at every match where the number of spectators is expected to exceed 2000, the club should employ a medical practitioner trained and competent in advanced first aid who would be present and available to deal with any medical emergency at the ground. When the crowd is not expected to exceed 3000, the role of the crowd doctor may be taken on by the club doctor provided that he is trained and competent in immediate medical care and on the strict understanding that his first priority is the crowd. For matches with an expected crowd of less than 2000, a suitably trained doctor should be available within 10 minutes, if not present in the ground.

The report also emphasises the need for skills in communication, command, and control, as essential components of major incident management. Liaison meetings with the police, ambulance service, first aid organisations, and the stadium manager should be held before every match as well as at the start of the season. The doctor should also be familiar with the major incident plan covering the stadium.

Doctors who have undertaken relevant courses are considered preferable, and the report goes on to recommend that those with- out such certification should attend a special day course in immediate medical care. The English Football Association currently runs two separate one day courses to meet these requirements, with attendance mandatory for all crowd doctors of English football clubs. Club doctors are encouraged to attend.

It appears that the recommendations of the Gibson Report have not been fully implemented in Scotland and that the results of our study have established a need for further training. Although a number of doctors have attended relevant courses, many do not have any basic formal training in resuscitation or major incident management.

Every stadium should possess a major incident plan which details the essential roles undertaken in the immediate response to a disaster. Of the doctors questioned, $44 \%$ were unaware of the major incident plan for their stadium. This fact allied to the lack of liaison meetings with the other emergency services could significantly impair the efficiency of the initial response.

In Scotland the crowds at professional football matches range from a few hundred to over fifty thousand. While the major stadiums may represent the most likely environment for a major crowd disaster, there is also a realistic risk of such an event occurring at the smaller club stadiums, where the crowd density for certain fixtures may be as high within a less modern stadium. It should also be noted that any distinction between club and crowd doctor would be irrelevant in the face of a major crowd incident and, as such, training is essential for doctors filling either role.

Importantly, $81 \%$ felt that an appropriately constructed course would be of benefit and confirms that training should be considered a priority. The vast majority of these doctors work on a voluntary unpaid basis, and the provision of a course by the Scottish Football Association may be the best way to improve standards. Any such course should contain elements of the ALS, ATLS, PALS, and MIMMS courses.

\section{CONCLUSION}

All doctors present in a professional capacity at football matches should be expected to have a certain basic level of training appropriate to the potential problems of crowd events. There is a need for both a heightened awareness of the Gibson recommendations and, more particularly, formal training in resuscitation and major incident management for doctors attending football matches.

1 Advanced Life Support Group. Major incident medical management and support. London: BMJ Publishing Group, 1995:6

2 Gibson RM. Report of the medical working party. London: HMSO, 1990

3 Wardrope J, Ryan F, Clark G, et al. The Hillsborough tragedy. BMF 1991;303:1381-5.

4 Hadden WA, Kelly S, Pumford N. Medical cover for the Open Golf Championship. BrF Sports Med 1992;26:125-7.

Take home message

The Scottish Football Association should take responsibility for ensuring that the recommendations of the Gibson Report are met. The current situation is unsatisfactory. 